\title{
THE USE OF FUZZY SET THEORY IN EXPLOITATION MANAGEMENT PROCESS ON THE WATER SUPPLY NETWORK
}

\section{WYKORZYSTANIE TEORII ZBIORÓW ROZMYTYCH W PROCESIE ZARZĄDZANIA EKSPLOATACJĄ SIECI WODOCIĄGOWEJ}

\author{
Izabela Piegdoń, Barbara Tchórzewska-Cieślak \\ Rzeszów University of Technology \\ e-mail: piegi@prz.edu.pl; cbarbara@prz.edu.pl
}

\begin{abstract}
Daily exploitation of the network, collected data base concerning the pipes failures and knowledge of employees forming the base of data using in effective failure removal process. The paper presents a methodology of assessment of technical condition of water pipes, based on ranking the failures and danger degree they present resulting the lack of water supply to the water consumers. Often decision making process take place under uncertainty conditions, therefore presented method is based on assessment of degree of danger pipe failure making by experts using fuzzy theory and fuzzy sets. In the paper a fuzzy graph including various types of failures causing lack of water supply was presented.
\end{abstract}

Keywords: water supply network, failure rate, theory of fuzzy set

Streszczenie: Codzienna eksploatacja sieci, zbiór danych dotyczących awaryjności przewodów oraz wiedza pracowników stanowia baze danych wykorzystywanych w procesie efektywnego usuwania awarii. W pracy zaproponowano metodyke oceny stanu technicznego przewodów, bazująca na szeregowaniu uszkodzeń względem stopnia stwarzanego przez nie zagrożenia skutkujacego brakiem dostawy wody do odbiorców. Często decyzje o usuwaniu awarii podejmuje się w warunkach niepewności, dlatego zaprezentowana metoda opiera się na dokonaniu oceny stopnia niebezpieczeństwa awarii przez ekspertów wykorzystujac tym samym logike oraz zbiory rozmyte (ang. fuzzy logic, fuzzy sets). W pracy zaprezentowano graf szeregu rozmytego uwzględniajacego typy uszkodzeń powodujących brak dostawy wody.

Słowa kluczowe: sieć wodociagowa, awaryjność, teoria zbiorów rozmytych 
The use of fuzzy set theory in exploitation management process...

Wykorzystanie teorii zbiorów rozmytych $w$ procesie zarzadzania eksploatacja...

\section{Wprowadzenie}

Sieć wodociągowa w każdej aglomeracji miejskiej jest strategicznym elementem infrastruktury krytycznej. Niezawodność funkcjonowania sieci wodociągowej definiowana jest jako zdolność sieci do realizacji swoich funkcji w określonych warunkach, poprawnej eksploatacji oraz w ciągu założonego czasu [5]. W przypadku systemów wodociągowych funkcje te polegają na dostarczeniu wody do odbiorców o odpowiedniej jakości, wymaganym ciśnieniu i o każdej porze dogodnej dla jej odbiorcy. W celu zapobiegania możliwości obniżenia niezawodności systemu skutkującego brakiem dostawy wody do odbiorców, możliwe jest dokonanie analizy i oceny ryzyka braku dostawy wody wykorzystując dostępne w literaturze metody [14], [15], [8].

Zastosowanie probabilistycznych metod analizy i oceny ryzyka braku dostawy wody do odbiorców, na skutek awaryjności przewodów wodociągowych wymaga jednoznacznego określenia przyczyn oraz skutków wywołanych przez dane zdarzenie niepożądane. Analizę ryzyka braku dostawy wody można wykonać posługując się metodami statystycznymi oraz probabilistycznymi w przypadku gdy dysponujemy kompletną oraz wiarygodną bazą danych. Natomiast jej brak bądź jej forma niekompletna (niepełna) umożliwia wykorzystanie w analizie ryzyka metod opartych na logice rozmytej [3], [1], [2], [6], [12].

Głównym celem pracy jest przedstawienie możliwości zastosowania teorii zbiorów rozmytych w procesie zarządzania eksploatacją na sieci wodociągowej. Metoda stanowi ocenę zdarzeń niepożądanych skutkujących brakiem dostawy wody do odbiorców. Metodyka bazuje na hierarchizacji typów zdarzeń niepożądanych (awarii) wg stopnia zagrożenia jakie stwarza w odniesieniu do konsumentów wody. W celu zilustrowania relacji zachodzących między typami zdarzeń zaproponowano rozmyty graf uszkodzeń.

\section{Modelowanie rozmyte}

Pojęcie zbiorów rozmytych (ang. fuzzy sets) zostało wprowadzone w 1965r. przez Lotfi A. Zadeh [16] z Uniwersytetu w Berkeley, co dało początek matematycznemu modelowaniu wielkości i zjawisk, które mają charakter wieloznaczny oraz nieprecyzyjny. Zbiory rozmyte służą do analizy tzw. pojęć lingwistycznych tj. opisanych za pomocą słów. W odróżnieniu od zbioru klasycznego, granica zbioru rozmytego nie jest konkretnie ustalona. Istnieje natomiast możliwość jego ustalenia za pomocą tzw. funkcji przynależności $\mu_{\mathrm{A}}$ (ang. membership function), w której A jest przestrzenią rozważań [16], [2]. Wartościami funkcji przynależności są liczby rzeczywiste $\mathrm{z}$ przedziału domkniętego $[0,1]$. Wartość funkcji przynależności na danym elemencie określa jego stopień przynależności do zbioru rozmytego A.

Rozróżnić można trzy przypadki [7]:

- $\mu_{\mathrm{A}}(\mathrm{x})=1$ pełna przynależność do zbioru rozmytego $\mathrm{A}$,

- $\mu_{\mathrm{A}}(\mathrm{x})=$ brak przynależności do zbioru rozmytego $\mathrm{A}$,

- $0<\mu_{\mathrm{A}}(\mathrm{x})<1$ częściowa przynależności do zbioru rozmytego A. 
Można zatem zapisać, że zbiorem rozmytym A w przestrzeni rozważań jest zbiór uporządkowanych par postaci:

$$
A=\left\{\left(x, \mu_{A}(\mathrm{x})\right) ; \mathrm{x} \in \mathrm{X}, \mu_{A}(x) \in X\right.
$$

Modelowanie rozmyte znalazło szerokie zastosowanie $\mathrm{w}$ istniejących systemach technicznych [3], [4]. Należą do nich modele samonastrajające się na bazie danych pomiarowych, model Mamdaniego, model Takagi-Sugeno-Kanga oraz modelowanie za pomoca eksperta. Umożliwia ona stworzenie zestawu odpowiednich zmiennych lingwistycznych oraz zbioru reguł typu IF (przesłanka)...THEN (konkluzja)... przez eksperta posiadającego wystarczająca wiedzę o modelowanym systemie technicznym. Jednym z głównych problemów podczas stosowania tej metody jest najczęściej wiedza „intuicyjna” niż ściśle określona.

Na typowy rozmyty model decyzyjny składają się cztery podstawowe kroki [1], [7]:

- blok rozmywania (ang. fuzzyfication) - na tym etapie konkretna wartość liczbowa kojarzona jest $\mathrm{z}$ daną zmienną lingwistyczną za pomocą założonych funkcji przynależności i ich parametrów,

- tworzenie bazy reguł oraz założenie modelu wnioskowania rozmytego. Na bazę reguł składa się zbiór pewnych rozmytych reguł postaci:

$\operatorname{IF}\left(x_{1}\right.$ jest $\left.A_{1}\right)$ AND ...AND $\left(x_{n}\right.$ jest $\left.A_{n}\right)$ THAN $\left(y_{1}\right.$ jest $\left.B_{1}\right)$ AND ...AND $\left(y_{n}\right.$ jest $\left.B_{n}\right)$, gdzie $A_{i}, B_{i}$ oznaczają zbiory rozmyte, $x_{i}$ jest daną wejściową natomiast $\mathrm{y}_{\mathrm{i}}$ zmienną wyjściową modelu lingwistycznego,

- blok wnioskowania (inferencji) - w tym bloku ma miejsce uruchomienie każdej z reguł, której przesłanki są spełnione. Na podstawie bazy reguł oraz danych wejściowych, tzn. znajomości stopnia przynależności,

- blok wyostrzenia (ang. defuzzyfication) - polega na zdefiniowaniu konkretnej wartości końcowej, wówczas gdy wartością wyjściową jest wartość rozmyta.

\section{Założenia modelu rozmytego}

Zbiory rozmyte służące do analizy pojęć lingwistycznych, wykorzystać można w procesie klasyfikowania przewodów wodociągowych do remontu. W takim przypadku pracownicy pogotowia wodociągowego mogą uwzględnić szereg licznych, trudno porównywalnych zmian powodujących uszkodzenia na sieci wodociągowej. Wybór przez eksperta typu uszkodzenia $\mathrm{x}_{\mathrm{i}} \mathrm{z}$ pośród całego zbioru uszkodzeń X opisanego

$$
X=<x_{1}, \mathrm{x}_{2}, x_{3} \ldots x_{n}>
$$

prowadzi do stworzenia listy typów uszkodzeń. Działanie to pozwala na ocenę zdarzeń niepożądanych skutkujących największymi stratami oraz długoterminowym brakiem dostawy wody do odbiorców. Modelowanie rozmyte pozwala na poddanie analizie zbioru danych, o różnym stopniu dokładności.

Wynikiem modelowania rozmytego jest „hierarchizacja” uszkodzeń, które miały miejsce $\mathrm{w}$ przeszłości celem wyeliminowania ich następstw w przyszłości. 
The use of fuzzy set theory in exploitation management process...

Wykorzystanie teorii zbiorów rozmytych w procesie zarzadzania eksploatacja...

Hierarchizacją nazywamy uporządkowany zbiór uszkodzeń zgodnie z zależnością (2) wg stopnia stwarzającego zagrożenie. Jedną z metod stosowanych przy tworzeniu hierarchii zgłoszeń jest stosowanie funkcji przynależności (liczb naturalnych z przedziału [0,1]), która charakteryzuje stopień niebezpieczeństwa danego typu uszkodzeń. Zaproponowano pięciostopniową klasyfikację stopnia niebezpieczeństwa (SNB), zależną od negatywnych skutków jakie może wywołać poszczególny typ uszkodzeń (tabela 2). Klasyfikację przyjęto na podstawie wieloletnich badań oraz wiedzy ekspertów. Jest to metoda szeroko stosowaną ze względu na jej prostotę oraz jej możliwości adaptacyjne , [10], [11].

Kolejnym krokiem jest umiejscowienie uszkodzeń w konkretnym miejscu przedziału liczbowego, tworząc cały zbiór. W celu określenia relacji łączących poszczególne typy uszkodzeń określić można skalę ocen, na którą składają się wartości funkcji przynależności - liczby rzeczywiste z przedziału. Funkcja ta każdemu elementowi ze zbioru $\mathrm{X}$ (uszkodzeniom) przypisuje stopień przynależności do zbioru rozmytego.

\section{Rozmyty model hierarchizacji uszkodzeń na sieci wodociągowej}

W przyjętym modelu w celu zwiększenia dokładności oceny zdarzeń, każdorazowo porównuje się typy uszkodzeń parami [9]. By określić relacje jakie zachodzą między dwoma typami uszkodzeń $\mu_{\mathrm{X}}\left(\mathrm{x}_{\mathrm{i}}, \mathrm{x}_{\mathrm{j}}\right)$, (jednego uszkodzenia względem drugiego) przyjęto wartości funkcji przynależności na podstawie dokonanej oceny lingwistycznej (tabela 1) [9], [13]:

Tabela 1. Opis lingwistyczny parametru $x$

\begin{tabular}{|l|c|}
\hline \multicolumn{1}{|c|}{ Wartość zmiennych lingwistycznych } & $\begin{array}{c}\text { Wartość funkcji przynależności } \\
\mu_{\mathrm{X}}\end{array}$ \\
\hline Uszkodzenie absolutnie poważniejsze & 1,0 \\
\hline Uszkodzenie zdecydowanie poważniejsze & 0,9 \\
\hline Uszkodzenie znacznie poważniejsze & 0,75 \\
\hline Uszkodzenie jednakowo poważne & 0,5 \\
\hline
\end{tabular}

Wartości przypisane uszkodzeniom $\left(\mathrm{x}_{\mathrm{i}}, \mathrm{x}_{\mathrm{j}}\right)$ należą do przedziału otwartego $(0,5 ; 1)$. Przyjąć można, że suma związku jaki zachodzi pomiędzy uszkodzeniem $\mathrm{x}_{\mathrm{i}}$ względem $x_{j}$ oraz $x_{j}$ względem $x_{i}$ równa jest jeden co przedstawia równanie [9]:

$$
\mu_{X}\left(x_{i}, x_{j}\right)+\mu_{X}\left(x_{j}, x_{i}\right)=1
$$

Przypisując każdej parze typów uszkodzeń wartości $\mu_{\mathrm{A}}\left(\mathrm{x}_{\mathrm{i}}, \mathrm{x}_{\mathrm{j}}\right)$ oraz zakładając, że

$$
\mu_{X}\left(x_{i}, x_{j}\right)=1-\mu_{X}\left(x_{j}, x_{i}\right)
$$

oraz

$$
\mu_{X}\left(x_{i}, x_{i}\right)=0
$$

otrzymujemy rozmyty model relacji zachodzących pomiędzy różnymi rodzajami uszkodzeń występującymi na sieci wodociągowej. 
Szereg kolejki opisującej rodzaj uszkodzenia oraz stopień stwarzanego przez nie zagrożenia przedstawiono za pomocą algorytmu (rysunek 1):

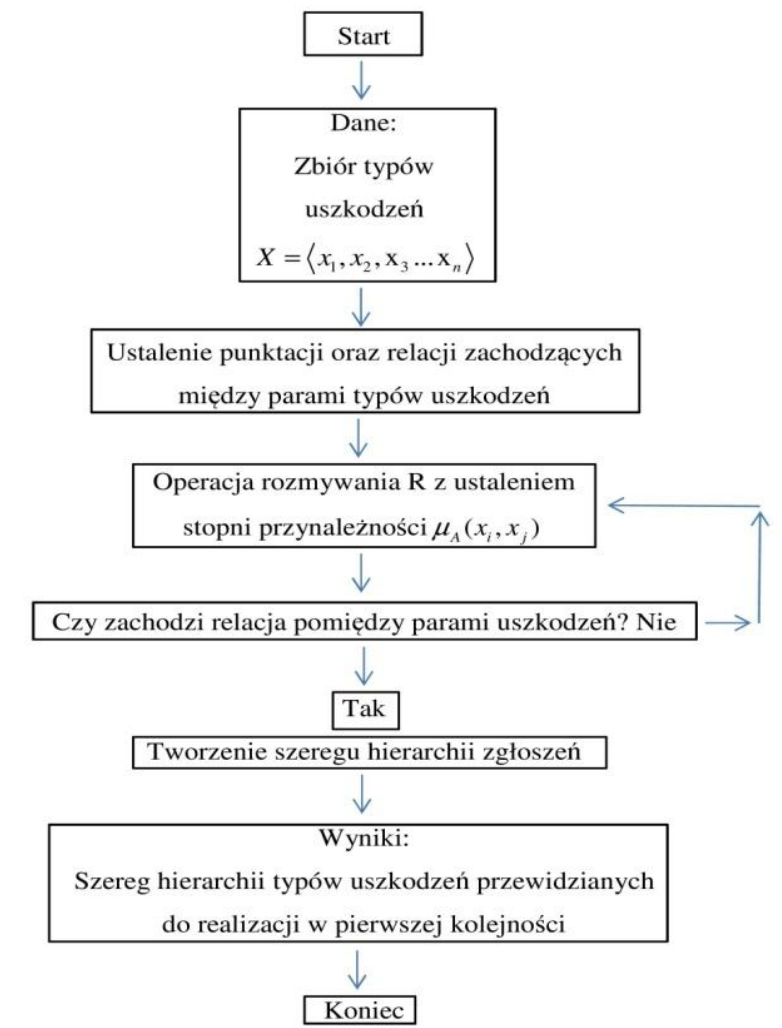

Rys.1 Schemat algorytmu tworzenia szeregu zgłoszeń

$\mathrm{Na}$ rysunku 2 przedstawiono graf uszkodzeń łączący uszkodzenie najbardziej niebezpieczne $\mathrm{z}$ najmniej niebezpiecznym uwzględniając przy tym negatywne skutki, jakie mogą wywołać. Dodatkowo na graf można nanieść wartości funkcji przynależności poszczególnych typów uszkodzeń, które przedstawiają zależności (relacje) uszkodzenia $x_{i}$ względem $x_{j}$.

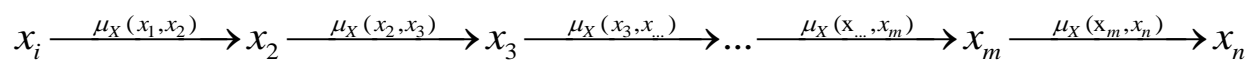

Rys.2 Ramię grafu szeregu typów uszkodzeń

\section{Przykład zastosowania}

Miasto Rzeszów zaopatrywane jest w wodę za pomocą brzegowo-komorowego ujęcia wody o wydajności $84000 \mathrm{~m}^{3} / \mathrm{d}$. Łączna długość eksploatowanej sieci wodociągowej wynosi $894,1 \mathrm{~km}$ (stan na rok 2013). Sieć magistralna o długości $49,8 \mathrm{~km}$ wykonana jest z przewodów żeliwnych oraz stalowych. Sieć rozdzielczą tworzą przewody wykonane z żeliwa, stali, PE i PVC o łącznej długości 520,5km. Przyłącza wodociągowe o długości 323,8 wykonane głównie ze stali ocynkowanej, 
The use of fuzzy set theory in exploitation management process...

Wykorzystanie teorii zbiorów rozmytych $w$ procesie zarzadzania eksploatacja...

żeliwa, PE i PVC. Sieć wodociągowa w 80\% wykonana jest w układzie zamkniętym. Z siecią przewodów wodociągową współpracują dwa zespoły zbiorników wodociągowych o łącznej pojemności $33100 \mathrm{~m}^{3}$. Przykład aplikacyjny zrealizowano na podstawie danych uzyskanych od Miejskiego Przedsiębiorstwa Wodociągów i Kanalizacji w Rzeszowie. Dokonano uszeregowania typów uszkodzeń zaobserwowanych oraz zanotowanych w trakcie eksploatacji sieci wodociągowej. Wymienione typy uszkodzeń przedstawiono w oparciu o klasyfikację uszkodzeń prowadzoną $\mathrm{w}$ przedsiębiorstwie wodociągowym. Analizę wykonano w oparciu o dane eksploatacyjne z lat 2005-2012. Z pośród odnotowanych typów uszkodzeń (uszkodzenie uznaje się jako zmienną lingwistyczną) wyróżnić można następujące ich rodzaje zgodnie z tabelą 2:

Tabela 2. Charakterystyka parametru $x$

\begin{tabular}{|c|c|c|c|}
\hline$X$ & Typ uszkodzenia & $\begin{array}{c}\text { Zagrożenia związane ze zdarzeniem } \\
\text { niepożądanym }\end{array}$ & $\begin{array}{c}\text { Stopień } \\
\text { niebezpieczeństwa } \\
\text { SNB }\end{array}$ \\
\hline $\mathrm{x}_{1}$ & $\begin{array}{l}\text { Rozszczelnienie } \\
\text { l.uszkodzeń - } 718\end{array}$ & $\begin{array}{l}\text { brak dostawy wody }<2 \mathrm{~h} \text {, lokalne } \\
\text { obniżenie ciśnienia wody, }\end{array}$ & Bardzo mały \\
\hline $\mathrm{x}_{2}$ & $\begin{array}{c}\text { Złamanie } \\
\text { l.uszkodzeń - } 274\end{array}$ & $\begin{array}{l}\text { brak dostawy wody }(2 \div 6>\mathrm{h}, \\
\text { lokalne obniżenie ciśnienia wody, } \\
\text { pojedyncze skargi konsumentów, } \\
\text { straty finansowe, }\end{array}$ & Mały \\
\hline $\mathrm{x}_{3}$ & $\begin{array}{c}\text { Korozja } \\
\text { 1.uszkodzeń - } 948\end{array}$ & $\begin{array}{l}\text { brak dostawy wody }(2 \div 6>\mathrm{h}, \\
\text { skargi konsumentów, pogorszenie } \\
\text { jakości wody, straty finansowe, } \\
\text { lokalne obniżenie ciśnienia wody, }\end{array}$ & Średni \\
\hline $\mathrm{x}_{4}$ & $\begin{array}{c}\text { Pęknięcie } \\
\text { 1.uszkodzeń - } 125\end{array}$ & $\begin{array}{l}\text { brak dostawy wody }(6 \div 12>\mathrm{h}, \\
\text { skargi konsumentów, straty } \\
\text { finansowe, spadek ciśnienia wody w } \\
\text { sieciwodociągowej, }\end{array}$ & Duży \\
\hline $\mathrm{X}_{5}$ & $\begin{array}{l}\text { Uszkodzenie } \\
\text { mechaniczne } \\
\text { 1.uszkodzeń - } 5\end{array}$ & $\begin{array}{l}\text { brak dostawy wody }(12 \div 24) \text { h, liczne } \\
\text { skargi konsumentów, znaczące straty } \\
\text { finansowe jak i społeczne, }\end{array}$ & Bardzo duży \\
\hline
\end{tabular}

W kolejnym etapie na podstawie subiektywnej wiedzy eksperckiej dotyczącej eksploatacji sieci wodociągowej, ustalono związki między uszkodzeniami. Działanie to pozwoli na podjęcie odpowiednich decyzji w procesie eksploatacji sieci wodociągowej.

W celu przeprowadzenia procesu wnioskowania zdefiniowano bazę reguł na podstawie wiedzy eksperckiej oraz dostępnych danych o systemie:

- uszkodzenie $\mathrm{x}_{1} \mathrm{z} \mathrm{x}_{2}$ - uszkodzenie $\mathrm{x}_{2}$ jest zdecydowanie poważniejsze od $\mathrm{x}_{1} \rightarrow \mu_{\mathrm{X}}\left(\mathrm{x}_{2}, \mathrm{x}_{1}\right)=0,90$,

- uszkodzenie $\mathrm{x}_{1} \mathrm{z} \mathrm{x}_{3}$ - uszkodzenie $\mathrm{x}_{1}$ jest znacznie poważniejsze od $\mathrm{x}_{3} \rightarrow \mu_{\mathrm{X}}\left(\mathrm{x}_{1}, \mathrm{x}_{3}\right)=0,75$,

- uszkodzenie $\mathrm{x}_{1} \mathrm{z} \mathrm{x}_{4}$ - uszkodzenie $\mathrm{x}_{4}$ jest zdecydowanie poważniejsze od $\mathrm{x}_{1} \rightarrow \mu_{\mathrm{X}}\left(\mathrm{x}_{4}, \mathrm{x}_{1}\right)=0,90$,

- uszkodzenie $\mathrm{x}_{1} \mathrm{z} \mathrm{x}_{5}$ - uszkodzenie $\mathrm{x}_{5}$ jest absolutnie poważniejsze od $\mathrm{x}_{1} \rightarrow \mu_{\mathrm{X}}\left(\mathrm{x}_{5}, \mathrm{x}_{1}\right)=1,0$,

- uszkodzenie $\mathrm{x}_{2} \mathrm{z} \mathrm{x}_{3}$ - uszkodzenie $\mathrm{x}_{2}$ jest absolutnie poważniejsze od $\mathrm{x}_{3} \rightarrow \mu_{\mathrm{X}}\left(\mathrm{x}_{2}, \mathrm{x}_{3}\right)=1,0$,

- uszkodzenie $\mathrm{x}_{2} \mathrm{z} \mathrm{x}_{4}$ - uszkodzenie $\mathrm{x}_{2}$ jest jednakowo poważne co $\mathrm{x}_{4} \rightarrow \mu_{\mathrm{X}}\left(\mathrm{x}_{2}, \mathrm{x}_{4}\right)=0,50$, 
- uszkodzenie $\mathrm{x}_{2} \mathrm{z} \mathrm{x}_{5}$ - uszkodzenie $\mathrm{x}_{5}$ jest absolutnie poważniejsze od $\mathrm{x}_{2} \rightarrow \mu_{\mathrm{X}}\left(\mathrm{x}_{5}, \mathrm{x}_{2}\right)=1,0$,

- uszkodzenie $\mathrm{x}_{3} \mathrm{z} \mathrm{x}_{4}$ - uszkodzenie $\mathrm{x}_{4}$ jest znacznie poważniejsze od $\mathrm{x}_{3} \rightarrow \mu_{\mathrm{X}}\left(\mathrm{x}_{4}, \mathrm{x}_{3}\right)=0,75$,

- uszkodzenie $\mathrm{x}_{3} \mathrm{z} \mathrm{x}_{5}$ - uszkodzenie $\mathrm{x}_{5}$ jest absolutnie poważniejsze od $\mathrm{x}_{3} \rightarrow \mu_{\mathrm{X}}\left(\mathrm{x}_{5}, \mathrm{x}_{3}\right)=1,0$,

- uszkodzenie $\mathrm{x}_{4} \mathrm{z} \mathrm{x}_{5}$ - uszkodzenie $\mathrm{x}_{5}$ jest jednakowo poważne co $\mathrm{x}_{4} \rightarrow \mu_{\mathrm{X}}\left(\mathrm{x}_{5}, \mathrm{x}_{4}\right)=0,50$.

Związki zachodzące pomiędzy typami uszkodzeń oraz zachodzące między nimi relacje rozmyte przedstawiono w postaci macierzy (tabela 3 ). W tym celu wykorzystano wzór (3) oraz (5).

Tabela 3. Rozmyta macierz uszkodzeń

\begin{tabular}{|c|c|c|c|c|c|}
\hline $\mathrm{X}$ & $\mathrm{x}_{1}$ & $\mathrm{x}_{2}$ & $\mathrm{x}_{3}$ & $\mathrm{x}_{4}$ & $\mathrm{x}_{5}$ \\
\hline $\mathrm{x}_{1}$ & 0 & 0,10 & 0,25 & 0,10 & 0 \\
\hline $\mathrm{x}_{2}$ & 0,90 & 0 & 1,0 & 0,50 & 0 \\
\hline $\mathrm{x}_{3}$ & 0,75 & 0 & 0 & 0,25 & 0 \\
\hline $\mathrm{x}_{4}$ & 0,90 & 0,50 & 0,75 & 0 & 0,50 \\
\hline $\mathrm{x}_{5}$ & 1,0 & 1,0 & 1,0 & 0,50 & 0 \\
\hline
\end{tabular}

W celu zminimalizowania prawdopodobieństwa popełnienia błędu podczas przydzielania zależności zachodzących między uszkodzeniami, możliwe jest dokonanie przekształcenia relacji rozmytej w postać ścisłej preferencji o funkcji przynależności zgodnie $\mathrm{z}$ formułą [9]:

$$
\mu_{R}^{S}=\left[\mu\left(x_{i}, x_{j}\right)-\mu\left(x_{j}, x_{i}\right)\right]
$$

W kolejnym etapie wytypowano uszkodzenia stwarzających największe zagrożenie oraz powodujące największe straty. Proponuje się stworzyć szereg typów uszkodzeń oraz graf uszkodzeń. Szereg należy budować stopniowo, szukając uszkodzeń najniebezpieczniejszych tj. mających najwyższy stopień przynależności uszkodzenia $\mathrm{x}_{\mathrm{i}}$ względem $\mathrm{x}_{\mathrm{j}}$ oraz $\mathrm{x}_{\mathrm{j}}$ względem $\mathrm{x}_{\mathrm{i}}$.

Po przeanalizowaniu danych otrzymanych $w$ tabeli 1 oraz porównując uszkodzenia ze sobą wytypować można następujące pary uszkodzeń zgodnie z tabelą 4.

Tabela 4. Zestawienie danych rozmytych

\begin{tabular}{|l|l|l|}
\hline$\mu_{\mathrm{X}}\left(\mathrm{x}_{1}, \mathrm{x}_{2}\right)=0,10$, & $\mu_{\mathrm{X}}\left(\mathrm{x}_{3}, \mathrm{x}_{1}\right)=0,70$, & $\mu_{\mathrm{X}}\left(\mathrm{x}_{5}, \mathrm{x}_{1}\right)=1,00$, \\
$\mu_{\mathrm{X}}\left(\mathrm{x}_{1}, \mathrm{x}_{3}\right)=0,25$, & $\mu_{\mathrm{X}}\left(\mathrm{x}_{3}, \mathrm{x}_{2}\right)=1,00$, & $\mu_{\mathrm{X}}\left(\mathrm{x}_{5}, \mathrm{x}_{2}\right)=1,00$, \\
$\mu_{\mathrm{X}}\left(\mathrm{x}_{1}, \mathrm{x}_{4}\right)=0,10$, & $\mu_{\mathrm{X}}\left(\mathrm{x}_{3}, \mathrm{x}_{4}\right)=0,25$, & $\mu_{\mathrm{X}}\left(\mathrm{x}_{5}, \mathrm{x}_{3}\right)=1,00$, \\
$\mu_{\mathrm{X}}\left(\mathrm{x}_{1}, \mathrm{x}_{5}\right)=0$ & $\mu_{\mathrm{X}}\left(\mathrm{x}_{3}, \mathrm{x}_{5}\right)=0$, & $\mu_{\mathrm{X}}\left(\mathrm{x}_{5}, \mathrm{x}_{4}\right)=0,50$. \\
\hline$\mu_{\mathrm{X}}\left(\mathrm{x}_{2}, \mathrm{x}_{1}\right)=0,90$, & $\mu_{\mathrm{X}}\left(\mathrm{x}_{4}, \mathrm{x}_{1}\right)=0,90$, & \\
$\mu_{\mathrm{X}}\left(\mathrm{x}_{2}, \mathrm{x}_{3}\right)=1,00$, & $\mu_{\mathrm{X}}\left(\mathrm{x}_{4}, \mathrm{x}_{2}\right)=0,50$, & \\
$\mu_{\mathrm{X}}\left(\mathrm{x}_{2}, \mathrm{x}_{4}\right)=0,50$, & $\mu_{\mathrm{X}}\left(\mathrm{x}_{4}, \mathrm{x}_{3}\right)=0,75$, \\
$\mu_{\mathrm{X}}\left(\mathrm{x}_{2}, \mathrm{x}_{5}\right)=0$, & $\mu_{\mathrm{X}}\left(\mathrm{x}_{4}, \mathrm{x}_{5}\right)=0,50$, \\
\hline
\end{tabular}


The use of fuzzy set theory in exploitation management process...

Wykorzystanie teorii zbiorów rozmytych $w$ procesie zarzadzania eksploatacja...

$\mathrm{Na}$ podstawie powyższego zestawienia uszeregowano oraz ustawiono kolejność rodzajów uszkodzeń poczynając od najniebezpieczniejszego (charakteryzującego się największym stopniem przynależności).

$$
x_{5}, x_{4}, x_{2}, x_{3}, x_{1}
$$

Zestawiając ze sobą uszkodzenia $\mathrm{x}_{2}, \mathrm{x}_{4}$ oraz $\mathrm{x}_{5}$ przypisano im $\mu_{\mathrm{x}}=0,50$ oznacza to, że są jednakowo niebezpieczne oraz że ich położenie $w$ szeregu może być przestawiane. Na rysunku 3 przedstawiono rozmyty graf szeregu uszkodzeń, uwzględniający SNB utraty wody przez konsumentów.

1,0

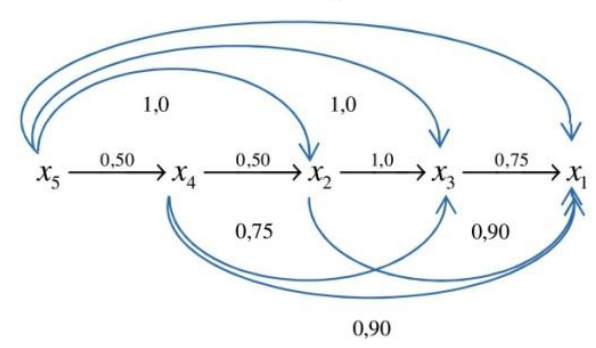

Rys.3 Graf szeregu rozmytego typów uszkodzeń powodujących brak dostawy wody

Z przeprowadzonej analizy wynika, iż najniebezpieczniejszym typem uszkodzeń, skutkującym długoterminowym brakiem dostawy wody są uszkodzenia $x_{5}$.

\section{Wnioski}

- W celu dokonania analizy oraz oceny ryzyka braku dostawy wody na podstawie awaryjności sieci wodociągowej niezbędna jest kompletna baza danych. Zaproponowana metoda stanowi połączenie metod analizy ryzyka zajścia zdarzeń niepożądanych (uszkodzeń na sieci wodociągowej) tj. metod matrycowych oraz metody rozmywania danych.

- Zaprezentowana klasyfikacja typów uszkodzeń miała na celu przedstawienie metodologii oceny stanu technicznego przewodów w oparciu o powszechnie stosowaną klasyfikację uszkodzeń przewodów wodociągowych. Analiza fizykomechaniczna uszkodzeń powinna być przedmiotem oddzielnych analiz i ocen.

- Poddanie analizie poszczególnych typów uszkodzeń zaistniałych na sieci wodociągowej pod kątem bezpieczeństwa dostawy wody do odbiorców, prowadzi do stworzenia narzędzia eksperckiego służącego poprawnej eksploatacji sieci w warunkach niepewnych (brak informacji o uszkodzeniach) oraz w podejmowaniu odpowiednich decyzji dotyczących modernizacji przewodów wodociągowych.

- W celu dokonania zaprezentowanej metody koniecznym jest przypisanie priorytetów uszkodzeniom oraz zanotowanie relacji jakie zachodzą pomiędzy poszczególnymi typami zdarzeń niepożądanych na sieci wodociągowej. Daje to możliwość zakwalifikowania konkretnego zbioru przewodów do renowacji. 
- Klasyfikowanie stopnia niebezpieczeństwa (SNB) każdej grupie uszkodzeń nie jest bezwzględnie wiarygodne. Należy wziąć pod uwagę specyfikę rozpatrywanego systemu dystrybucji wody, informacje dostępne w dziennikach awarii oraz wiedzę pracowników.

- Metoda umożliwia analizę różnego rodzaju uszkodzeń zarówno mających miejsce na sieci wodociągowej jak i innym systemie należącym do infrastruktury krytycznej, może być pomocna we wstępnej ocenie stanu technicznego przewodów oraz może być z powodzeniem wykorzystywana przez operatorów systemów wodociągowych.

\section{Bibliografia}

[1] Braglia M. Frosolini M., Montanari R., Fuzzy criticality assessment model for failure modes and effects analysis, International Journal of Quality \& Reliability Management, 20(4)/2003, s. 503-524.

[2] Dubois D. Prade H., Fuzzy sets and systems: Theory and application, Academic Press, Nowy Jork, 1980.

[3] Kacprzyk J., Zbiory rozmyte a analizie systemowej, Państwowe Wydawnictwo Naukowe, Warszawa, 1986.

[4] Kluska J. Rak J., Wieczysty A., Możliwość zastosowań logiki rozmytej, X Międzynarodowa Konferencja Naukowo-Techniczna "Gospodarka wodnościekowa w regionach rolniczo-przemysłowych", Wydawnictwo Poltechniki Białostockiej, Białystok, 1999, s. 141-149.

[5] Kwietniewski M. Rak J., Niezawodność infrastruktury wodociągowej i kanalizacyjnej w Polsce, Studia z zakresu inżynierii nr 67, Polska Akademia Nauk, Komitet Inżynierii Lądowej i Wodnej, Instytut Podstawowych Problemów Techniki, Warszawa, 2010.

[6] Lee H. M., Applying fuzzy set theory to evaluate the rate of aggregative risk in software development, Fuzzy Sets and Systems, Elsevier, 79(3)/1996, s. 323-336.

[7] Mamdani E.H., Application of fuzzy logic to approximate reasoning using linguistic systems, Fuzzy Sets and Systems, Elsevier, 26(12)/1977, s. 1182-1191.

[8] Piegdoń I. Tchórzewska-Cieślak B., Matrix analysis of risk of interruptions in water supply in terms of consumer safety, Journal of KONBiN. 2012, Wydawnictwo Instytutu Technicznego Wojsk Lotniczych, Warszawa. s. $125-140$.

[9] Przybyła B., Propozycja motody oceny stanu technicznego przewodów kanalizacyjnych z wykorzystaniem elementów teorii zbiorów rozmytych, Gaz, Woda i Technika Sanitarna, Wydawnictwo Sigma-NOT, 2/2014, s. 46-52.

[10] Rak J. Tchórzewska-Cieślak B., Review of matrix methods for risk assessment in water supply system, KONBIN, Wydawnictwo Instytutu Technicznego Wojsk Lotniczych, 1/2006, s. 67-76. 
The use of fuzzy set theory in exploitation management process...

Wykorzystanie teorii zbiorów rozmytych $w$ procesie zarzadzania eksploatacja...

[11] Tchórzewska-Cieślak B., Matrix method for estimating the risk of failure in the collective water supply system using fuzzy logic, Environment Protection Engineering, Oficyna Wydawnicza Politechniki Wrocławskiej, 37/2011, s. 111-118.

[12] Tchórzewska-Cieślak B., Model of risk of water mains failure using fuzzy logic, Journal of Polish Safety and Reliability Association, Polish Safety and Reliability Association, 1/2010, s. 255-264.

[13] Tchórzewska-Cieślak B., Rozmyty model ryzyka awarii sieci wodociągowej, Ochrona Środowiska, PZITS O/Dolnośląski, 33(1)/2011, s. 35-40.

[14] Tchórzewska-Cieślak B., Ryzyko związane z funkcjonowaniem systemu zaopatrzenia w wodę do spożycia, XXXV Zimowa Szkoła Niezawodności Problemy niezawodności systemów, Wydawnictwo Instytutu Technologii Eksploatacji - Państwowego Instytutu Badawczego, Szczyrk, 2007, s. 500-510.

[15] Tchórzewska-Cieślak B. Rak J., Piegdoń I., Risk analysis of water supply interruptions in collective water supply systems, 6th Summer Safety \& Reliability Seminars - SSARS 2012, Gdańsk - Sopot, 2012, 3, s. 201-207.

[16] Zadeh L. A., Fuzzy sets, Information and Control, Elsevier, 8(3)/1965, s. 338-353.

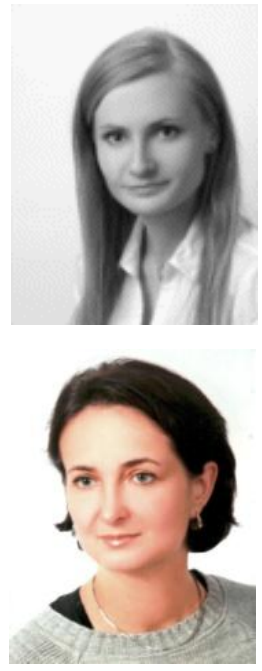

Mgr inz. Izabela Piegdoń pracuje na stanowisku asystenta $w$ Politechnice Rzeszowskiej w Katedrze Zaopatrzenia $w$ Wode $i$ Odprowadzania Ścieków. Zainteresowania naukowe niezawodność i bezpieczeństwo systemów inżynierskich, techniki informatyczne w zarzadzaniu systemami dystrybucji wody.

Dr hab. inż. Barbara Tchórzewska-Cieślak, prof. PRz pracuje na stanowisku profesora nadzwyczajnego $w$ Politechnice Rzeszowskiej w Katedrze Zaopatrzenia w Wode $i$ Odprowadzania Ścieków. Zainteresowania naukowe eksploatacja systemów zbiorowego zaopatrzenia $w$ wodę, niezawodność $i$ bezpieczeństwo systemów inżynierskich, niekonwencjonalne metody analizy i oceny ryzyka. 